\title{
Problems in the Development of Cultural Industry of Party Newspaper in China and Its New Media Developing Strategy
}

\author{
Long Yunrong and Zhang Shuhua
}

\begin{abstract}
The cultural industry is a smokeless and sun-rise industry of non-pollution, low consumption, high efficiency and high aggregation. Under the drive of a series of incentive developing policy, cultural industry of the party newspaper has developed very quickly in China. However, there are still many problems which restrict the development of the cultural industry of the party newspaper in China. So some measures should be taken to make full use of the advantages of new media to promote the development of cultural industry of the party newspaper.
\end{abstract}

Index Terms-Party newspaper, cultural industry, new media

\section{INTRODUCTION: CULTURAL INDUSTRIES OF THE PARTY NEWSPAPER AND ITS DEVELOPMENT STATUS}

Horkheimer and Adorno (2002) [1] first put forward the concept of cultural industry in 1947. They called the commercial industrialization production of entertainment, film, broadcast, publications and records and other economic activity as culture industry to distinguish it from the perspective of art and writing works of social activities. This definition was adopted by the United States, France, the European Union and other countries and regions develop the cultural industry policies. British government set up a specialized agency named "Creative Industries Task Force"to manage its culture, media and sport service. The agency was committed to make creative industries as British main industry development in the post-industrialization era. The category of the creative industries including film and television industry provided for high capital and industrialization mode, and the labor intensive and strong artistic crafts, music, design and visual and performing art consumption provided for mass consumption, this kind of industry is highly commercialized and easily affected by the business cycle effect (Flew, 2002)[2].The content of UK's creative industries is not much different from the United States, the European Union and other regional, so the western economists often did not distinguish between the cultural industry and creative industry in their study on cultural industry, and they were regarded as one word. William B.Beyers (2010) [3]studied cultural creative industries from the angle of service economy, and considered cultural and creative industry is a subclass of service industry, and cultural industry is to provide entertainment, sports consumption and artistic consumption service industry. Though this definition is very broad, because it is based on the angle of consumer and is very

Manuscript received July 29, 2016; revised August 23, 2016.

Long Yunrong is with School of Media at Hunan University of Science and Engineering, Yongzhou, Hunan, China (e-mail: longyunr@163.com).

Zhang Shuhua is with School of Sports at Hunan University of Science and Engineering, Yongzhou, Hunan, China. practical in actual economic statistics, so many scholars agreed.

The cultural industry, which has being developed on the background of the rapid rise of global consumer level and cultural consumption, is widely regarded as "sunrise industry ", "gold industry in the global economic integration times in 21 st century. The data shows that the world cultural industry creates $\$ 22$ billion daily, and in increasing by $5 \%$ per year (Scott, 1996) [4] Due to the positive role of the cultural industry on the national economy, Chinese scholars pay much attention on the culture industry research especially after the Chinese government announced the culture industry planning in 2009, and cultural industry research increasingly enriched. In September 2003, the Chinese Ministry of Culture defined the culture industry as "engaged in the production of cultural products and cultural services operating industry" in the document of "opinions to support and promote the development of cultural industries".

Depending on the product form, the cultural industry is basically divided into three categories: First, the productions and sales of cultural products rendered relatively independent of state industries, such as the production and sale of books, newspapers and magazines, television, film, audio and video products and other industries; Second, labors in the form of cultural services industry, such as theatrical dance performances, sports, entertainments, planning, brokerage, etc.; Third, cultural value-added industries to other commodities and industries, such as decorating, decoration, image design, culture travel.

According to the concept of cultural industries, cultural industries range includes: entertainment activities for the public to provide the physical form of cultural products such as books, newspapers, publishing, production, distribution and others; providing for public participation and cultural and entertainment services, such as radio and television services, film services, cultural performances service; providing cultural management and research services, such as the protection of cultural relics and cultural heritage, library services, cultural and social organizations activities; providing cultural, entertainment products production and operation of the equipment, materials production and sales activities, such as printing equipment, stationery and other activities; providing cultural, entertainment services necessary equipment, supplies, production and sales activities, such as radio and television equipment, film equipment, and other production and business activities; and culture, and other entertainment related activities, such as arts and crafts, and design activities. Therefore, the range of cultural industries of the party newspaper may include newspaper publishing industry, creative planning, and advertising production industry, copy, print design and packaging industry, 
newspapers and express logistics industry.

The cultural industry is a smokeless and sun-rising industry of non-polluting, low consumption, high efficiency and high aggregation. The development of cultural industry has become an important industry type for many countries racing to develop in the new media era all over the world, and also has become a pillar industry of the national economic development in many developed countries. Because the development of the cultural industry is not an important channel to meet the people's growing spiritual and cultural need and an important way to promote the transformation of the mode of economic production and development, but also is the necessary measures to enhance the national cultural security and overall national strength.

The emergence and development of cultural industry is the inevitable result of urbanization, and has many aspects effect on national economy. Main effect lies in the following respects: firstly, the development of cultural industry has changed people's consumption structure. According to the data from the Bureau of Economic Analysis (B E A) of the United States, the average per entertainment consumer spending accounted for income proportion rose to nearly $0.1 \%$ in 2005 from $0.06 \%$ in 1960 , formed sharply contrasts with the corresponding period of food, clothing, medical care and transportation spending. Secondly, the development of cultural industry can strongly promote employment. Markusen \& Schrock (2006) [5]'s research shows that, cultural and art industry self-employment attribute has created 22500000 employment opportunities only in 2004. Thirdly, the development of cultural industry has changed the mode of economic growth. Terry Flew and Stuart Cunningham (2010) [6]pointed out that culture industry total output value has exceeded the United States GDP $10 \%$ in 2008, and other developing countries including Australia, Singapore, South Africa and China have begun to energetically develop its cultural industry as to keep its sustainable economic development potential power source driven by the United States.

In November 2002, the 16th CPC National Congress for the first time distinguished the public culture industry and the profit culture industry, which got rid of the shackles to development of cultural industries. The reform of cultural system in 2003 was designed to remove the institutional and institutional obstacles to the development of cultural industries. the State Council issued the "Cultural Industry Promotion Plan" in 2009 rose the promotion of the development of cultural industries to the national strategic level, and put forward the development of new cultural formation with using new media .The central proposals on the development of the" 12th Five-Year Plan of National Economic and Social Development "in 2010 put forward the development goal to "promote the cultural industry to be a pillar of the national economy industries ". When it came to the development of cultural industry was an important way to enhance the national "soft power" efforts, the report of the 17th CPC National Congress stressed the need to innovate culture production methods and cultivate a new culture format with using high-tech.

Under a series of cultural industry supporting policies, such as encouraging investing and financing capital onto the cultural industry, speeding up the news publishing industry into enterprises, digital publishing, encouraging industry mergers and acquisitions integration, the regional support for cultural industries increased significantly, and A-share market is also set off a drama of capital onto the cultural industry especially onto the publishing industry. According to the figures released by the State Press and Publication Administration in 2009, the total output of the industry-wide news publishing industry was 1.06689 trillion Yuan, and the added value was 309.97 billion Yuan. 2010, the total output of national press and publishing, printing and distribution reproduction reached 1.27 trillion Yuan, and the added value was 350.34 billion Yuan. The national publishing, printing and distribution services in 2011 achieved operating income of 1.45686 trillion yuan, the added value was 402.16 billion Yuan. [7]The public listing of press and publishing enterprises made new progress, so far, the news publishing industry listed 49 companies with total assets of 368.01 billion Yuan, including Anhui New Media, South-central media, Tianzhou culture, Fangzhi science and technology.

\section{The Main Problems In the DeVelopment of CULTURAL INDUSTRIES OF THE PARTY NEWSPAPER IN CHINA}

Although the cultural industry has achieved rapid development, the development of cultural industries of the party newspaper, as an important part of cultural industries, are still facing many problems, which restrict the overall development of the party newspaper in China.

\section{A. The Financing Difficulties}

The development of any industry can't do without the support of capital especially in cultural industries. However, the current development of cultural industry in China is now facing a reality of lacking developing capital.

From the national level, despite the Chinese government attaches great importance to the development of cultural industries, the investment is not enough. Statistical data show that the financial support from the Chinese government 2010 onto cultural aspects was 8.957538 trillion Yuan accounting for only $0.36 \%$ of the national total fiscal expenditure. In fact, compared with 20th century, the fiscal expenditure of cultural undertakings sharing of the national total fiscal expenditure has been showed a downward trend since 2001. In 2010, the Chinese government investment in cultural undertakings capital is of 7.514 billion Yuan, compared with the cultural industry output value of 1.11 trillion in 2010, almost may be negligible. [8]From a market perspective, due to the characteristics of the industry, the cultural industry is of large-scale investment, intangible production and high bank-based investment' which make the main bodies have to concern about the moral hazard caused by information asymmetry and even abandon the financial support for the cultural industry .

It is necessary to enter the capital market if newspapers want to get strong financial support. While accessing to capital markets needs for high quality resources and capital, and good profit model, core team and enterprise 
management. But the party newspaper in China are facing the problem of shortage of capital because of small scale, weak economic, lacking of capacity in operating capital, and administrative management. 2011, in the contest of capital, there are not the success of the Zhejiang Daily Group, but also the fail of Southern Newspaper Group, even painful example of Beijing Youth Group, as well as CCID Media facing delisting. CCID Media ever issued recombinant notice twice 2011. Full-year profit of Beijing Youth Media decline by $32 \%$ in 2010 because of difficulty in finding an ideal investment point when it listed financial capital, so the financial funds is difficult to promote the development of the company.[9]

\section{B. Shortage of Talents Reserve}

Industrial development requires not the flow of funds but also talent reserve. The one hand, financial institutions do not understand culture while intellectuals do not understand the financial, which led to some problems in the cooperation of the financial and cultural. The other hand, the shortage of cultural industry talent reserve in China also restricts the development of the industry.

Cultural industries mainly lack of versatile talents and emerging industry professionals. High-quality management personnel of both broad view of humanity and intensive industrial concept is the imperative need for cultural industries. In Beijing, for example, the proportion of creative industry employment in total employment population is no more than $1 \%$. Not only the reserves of talent is not enough but also the structure is not reasonable, especially lacking of a number of top leader-style creative talent. By contrast, in New York, the practitioners of cultural and creative industries accounted for $12 \%$ of the total population of all the work of the city, $14 \%$ in London, as high as $15 \%$ in Tokyo.

Many emerging cultural industries, such as the convention and exhibition industry, online game industry, animation industry, copyright industry, lack professionals. Taking copyright industry for example, there are more than 500 publishing houses, more than 200 Electronic Audio and Video Publishing House, more than 9,000 magazines, more than 2,000 newspapers and millions of Web sites and other copyright-related industries in China, the current copyright agency is only 28 , which can't form the chain of cultural industry. The main reason is lacking of emerging industry professionals.

\section{Single Industrial Structure}

Although Zhejiang Daily Group, Chongqing Daily Group, Hubei Daily Group entered the cultural transmission, real estate, creative park, star hotel industry in 2011, from a general point of view, the majority of the party newspaper widespread China is of a single structure, imbalanced in the proportion of operating income, narrow range of industrial radiation, and has not formed a certain scale multi-industry chain. According to statistics, advertising revenues accounted for the proportion of the total revenue of the newspaper publishing unit is of up to $69.8 \%$, and advertising revenue has been direct "weathervane" of the newspaper operating income. Part of the party newspaper presents simple longitudinal structure of "the party newspaper - city newspaper-printing press - news website - advertising company" , while the development of horizontal industrial is still under developed. Therefore the inefficiency of core competitiveness of newspaper products and the imperfect of the industrial complementary mechanism seriously affect the ability of the newspaper to resist risks. 2009 Press and Publication Industry Analysis Report released by the General Administration of Press and Publication show, firstly that newspapers, periodicals, audio and video products, electronic publications and digital publishing combined total output, value added and operating income in the industry-wide respectively accounted for the proportion of $19.7 \%, 25.3 \%$ and $19.9 \%$, while the copyright trade, services and content planning, production and provide revenue in the proportion was less than $0.1 \%$ of the operating income, which could not fully and clearly reflect the news publishing industry as a essential characteristics of modern content industry. Secondly the proportion of operating income of mobile publishing and online games in the operating income of digital publishing is $71.3 \%$, the proportion of total operating income of digital journals, e-books and digital newspapers (online edition) is less than $3 \%$, which reflects the unbalance of the internal structure of digital publishing. Therefore it was noted that the currently thriving cultural industries but in reality is the culture of the real estate industry, the most construction of cultural industries are of commercial real estate in the end. For newspaper, whether the current cultural industry is a free "ride" or "trap" remains to be observed.

\section{Limited Resource Capacity}

The local party newspapers accounts for about half of the party newspaper in China. In local cities, the level of economic development is less developed than the capital city except for some few developed regions and cities. Most local party newspapers are facing the problem of smaller scale and less strength than what in capital city. Relatively development of economy, culture and education is underdeveloped, and the level of mass cultural consumption and urbanization is low, as a result the newspaper's circulation and profitability is affected. The small circulation of the party newspaper and the weak economic foundation restricts the newspaper's advertising revenue. Combined with the current diversified development of media, and the limited market resources was divided into fragmentations by TV, website, mobile media, and outdoor advertising, which weaken the party newspaper's ability to participate in market competition.

\section{E. The Backward Concept of Develop}

Confined to the traditional ideas, the market level of Chinese newspaper is low, and people are too sensitive to the ideology of cultural property. There are too much forbidden area to keep people from touching. Most people have strong interest and impulse in governing culture, and accustomed to treat the cultural industry with the thinking and approach in the planned economy period. Market access, market building, and configuration of cultural resources are mainly deal with administrative means, while the market yet has not played its due role in the configuration of cultural 
resources. The imperfect of market mechanism greatly hinders the pace of industrialization and marketization of culture, which leads to the weak vitality, slow speed and low effectiveness.

The newspaper has been developed as a career for a long time with neglecting its industrial property. Its political function especially was focused on and the importance of its economic function was not been paid on. The newspaper management pay too much attention to the guidance to the public opinion and too little attention to the industrial development, too much attention to the social attributes and too little attention to the economic function, too much attention to the administrative guidance and too little attention to the market development. Therefore the newspaper can't really become autonomous and self-financing market players, which weaken the market concepts and sense of competition of the newspaper, leading to the low marketization and slow process of industrialization.

\section{F. Highly Imbalanced Development}

The development of the party newspaper industry in general is in imbalance. The one hand is the regional imbalance, mainly due to the advanced market concepts and preferential policies, the industrial level of the party newspaper in the developed eastern coastal cities and southern open cities is much higher than that in the backward areas of the mainland and western regions. According to the General Administration of Press and Publication "2010 news publishing industry analysis report "shows: news publishing industry development of the developed eastern regions continue to maintain its leading position to the central and western part of the underdeveloped areas of the news publishing industry. In 2010, the overall size of the economy of Guangdong, Beijing, Zhejiang, Jiangsu, Shanghai and Shandong provinces accounted for the leading six, its total output, value added, total assets, owners' equity (net assets), operating income and profits respectively accounted for $61.1 \%, 59.7 \%, 59.7 \%, 56.5 \%, 61.3 \%$ and $57.4 \%$ of the national totality. The other hand is the internal imbalance. The external cultural industries, such as city newspapers and evening newspapers, relatively speaking, have developed faster than the core industry. Especially, the industrialization of the party newspaper publishing has not upgraded to the agenda.

\section{NeW MEdia StRategy TO DEVElop THE PARTY NEWSPAPER CULTURE INDUSTRY}

Recently the rapid development of new media technology at least deeply affects the development of the cultural industry in four aspects: firstly, provides advanced tools and manifestations for the cultural production, which makes its content more colorful and attractive; secondly, gives birth to a lot of the emerging culture of formats, such as electronic ticketing, internet culture, cell phone culture, 4D movies; thirdly, greatly expand the exportation and spreading channel; fourthly, multiple high-speed, large capacity of the channel, more urgent demand for cultural content give more opportunities for the content creation and production as the core of cultural industries. [10]Therefore the party newspaper should make full use of the advantages of the new media to promote the development of cultural industries of the party newspaper.

\section{A. Develop Digital News Publishing Industry}

Newspapers firstly are news printing. So the basic foundation for its development is to run well its news reporting. News reporting is the main segment of the newspaper industry. Only with growing influence and practical results of news reporting can the newspaper business win market, and can the newspaper industry get stronger and stronger. To develop the cultural industries, the party newspaper should be devoted themselves to high quality news reporting and construction of famous news columns, and to enhance its affinity, attraction and influence of the news reports, and should be committed to improving the core competitiveness, the continual executive power and the guiding force of public opinion and the market influence.

\section{B. Develop Digital Information Services Industry}

2011 Founder Electronics announced to create an integrated open cloud services platform "public cloud service model" concentrated with a set of resource processing, digital content production, sub production of digital content distribution, e-commerce in, as well as to build a unified digital operating platform for newspaper groups, and also to provide processing generating tool and operation services platform "private cloud service model" for a variety of new digital content products. September 15, the mobile media publishing platform "the cloud newspaper" on-line jointly launched by the GuangMing Daily Group and Founder Electronics Group, and the first digital newspaper "Cloud Morning" based on the platform also formally met with its readers. According to the plan, Guangming Daily Group and Founder Electronics Group will set up a joint venture company taking responsibility for operating the newspaper, and will attract more than 100 mainstream media within a year. It is reported that "the cloud newspaper" is known as complete mobile media publishing platform, and is applicable for different media to publish their own mobile new media quickly and access to a full range of services from content management to the subscription and user monitoring. Therefore the digital information services operating platform may be seen as an important direction of the development strategy for newspaper cultural industrial development in new media era.

\section{Develop the Creative and Design Advertising Production Industry}

Creativity and design is important types of cultural industry. Advertising is the main economic source of newspaper industry, and the implementation of social and economic benefits of the newspaper also depends on the development of advertising. The advertising of the party newspaper is more simple information publishing but less creativity and design. While the development of cultural industry of the party newspaper something more important is the development of innovative creativity and design especially the digitization and multimedialization of the 
advertising, creativity and design of the party newspaper with new media technology.

\section{Develop the Printing and Copying Industry}

According to the statistical reports from the National Press and Publication Administration in 2010, the total output of the printing and copying industry accounted for $64.4 \%$ of the total output of the news publishing industry, and the added value of $60.5 \%$, and the operating income of $64.0 \%$, far more than other industries, leading in the industry-wide. In 2011, printing and reproduction achieved operating income of 930.54 billion Yuan representing an increase of 138.72 billion Yuan in 2010 with an increase of $17.5 \%$ accounted for $63.9 \%$ of the total industry, and the added value was of 232.49 billion Yuan representing an increase of 20.43 billion Yuan with an increase of $9.6 \%$ accounted for $57.8 \%$ of the total industry, which showed the printing and copying industry has been the pillar industry of the news publishing industry and the development of printing and copy industry is an important economic growing point of the newspaper culture. The development of cultural industry of the party newspaper should make full advantage of new media technologies to develop the digital copying, printing and packaging design industry.

\section{E. Develop Modern Logistics Industry}

Recently faced with the huge impact of the e-commerce business, the newspaper groups all over China have enhanced investment in e-commerce and looked forward to share a piece of "cake". The Southern Newspaper Group has opened a group-buying platform integrating internal advertising, marketing, and distribution using all-media means, involved in the field of electronic commerce. The e-commerce Co., Ltd set up by Shenzhen Press Group 2011 also achieved rapid development in business innovation, platform construction, sales, restructuring development. Hubei Daily Group will also explore the construction of the internet of things and the development of chain sales and other industries based on its own logistics base. The National Urban Press Release Network Alliance founded in 2004 is a alliance taking publications as main body including the procurement of other value-added services, distribution, sales. Its members include 41 newspapers and issue units from provincial capital cities and independent planning cities. Total circulation of each unit reached 15 million per day, and annual advertising revenue was up to 100 billion, the employees was more than 10 million about half of the national total. [11]Recent years' practice has shown that the development of outdoor advertising, e-commerce and other new media business was an effective way of upgrading and restructuring of traditional newspaper with using their own advantages.

\section{CONCLUSION}

The cultural industry is a smokeless and sun-rise industry of non-pollution, low consumption, high efficiency and high aggregation. Under the drive of a series of incentive developing policy, cultural industry of the party newspaper has developed very quickly in China. However, there are still many problems which restrict the development of the cultural industry of the party newspaper in China. With the rapid development of new media technology deeply affects the development of the cultural industry. Therefore the party newspaper should make full use of the advantages of the new media to promote the development of cultural industries of the party newspaper. So some measures including developing digital news publishing industry, digital information services industry, the creative and design advertising production industry, the printing and copying industry, and modern logistics industry, should be taken to make full use of the advantages of new media to promote the development of cultural industry of the party newspaper.

\section{ACKNOWLEDGE}

2012 National Social Science Fund Project research on mass media and ethnic social and cultural change under the background of modernization (Grant No.12BMZ059)

\section{REFERENCES}

[1] M. Horkheimer and T. W. Adorno, Dialectic of Enlightenment, Stanford University Press, 2002.

[2] F. T. B. Hocery, "Defining the creative industries," in Proc. Cultural Sites, Cultural Theory, Cultural Policy, Second International Conference of Cultural Policy Research, Wellington, New Zealand, January 23-26, ed. Michael Volkerling, pp.181-191, 2002.

[3] B. W. Beyers, "Cultural and recreational industries in the United states," The Service Industries Journal, vol.2 8, no. 3, pp. 375-391, 2008.

[4] A. J. Scott, "The craft, fashion and cultural-products industries of los angeles: Competitive dynamics and policy dilemmas in a multi-sectoral image production complex," Annals of the Association of American Geographers, vol. 86, no. 2, pp. 306-323, 1996.

[5] M A. R. arkusen and A. Johnson, "Artists' centers: Evolution and impact on careers, neighborhoods and economies," Project on Regional and Industrial Economies, Humphrey Institute of Public Affairs, 2006.

[6] T. Flew and S. Cunningham, "Creative industries after the first decade of debate," The Information Society, no. 26, pp. 113-123, 2010 .

[7] Gapp.

[Online]. http://www.gapp.gov.cn/govpublic/60.shtml

Available:

[8] The Ministry of Culture of the People's Republic of China, Yearbook of China's Cultural Relics Statistic, The national library press of China, 2011.

[9] S. M. Huang and M. Tao, "Reviewing of China's newspapers 2011 and lookforward of 2012," China Newspaper Industry, no.1, 2011.

[10] M. Siwei. The current situation of the development of China's Culture industry. [Online]. Available: http://www.ccnt.gov.cn/preview/special/3425/3430/3449/201202/t20 120222_230215.html, 2012-02-22.

[11] J. W. Song, "Yearbook of China's newspaper," China Associated Press of Industry and Commerce, 2009.

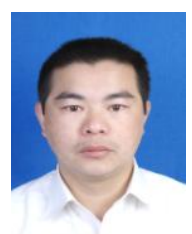

Long Yunrong is a doctor. He is from Yong Zhou, Hunan province, in China. $\mathrm{He}$ is a director of institution for new media and social development at Hunan University of Science and Engineering.

He received his bachelor in anthropology from South-Central University for Nationalities, WuHan, China from 1993 to 1997.

$\mathrm{He}$ received his master in anthropology from South-Central University for Nationalities, WuHan, China from 2005 to 2008.

He received his doctor in anthropology from South-Central University for Nationalities, Wuhan, China from 2008 to 2011. He mainly engaged in mass media and ethnic social-cultural changes, party news-paper development, cultural industry. 